\title{
The role of institutional pressures in the introduction of energy-efficiency innovations
}

\author{
Paola Garrone ${ }^{\mathrm{a}}$ \\ Luca Grilli ${ }^{\mathrm{a}}$

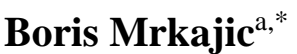 \\ a Department of Management, Economics and Industrial Engineering, Politecnico di Milano, \\ Via Lambruschini 4b, 20156 Milan, Italy \\ *Corresponding author contact: boris.mrkajic@polimi.it, +393202598439
}

\section{Abstract}

Relying on the institutional and innovation theories, we argue that the institutional features of countries are significantly influencing energy-efficiency innovation (EEI), a relevant and peculiar type of environmental innovation activities. An analysis of a cross-sectional sample of 22,936 firms from nine European countries, drawn from the 2006-2008 Community Innovation Survey, confirms the hypothesis that formal and informal institutions influence the propensity of firms to introduce EEIs in general. Furthermore, formal institutions that generate regulatory pressures are found to spur both product and process EEI activities, while informal institutions exerting social pressures emerge to be capable of significantly driving only product EEI activities. Large firms appear to be relatively more reactive to high regulatory pressures. We draw implications for policy makers and managers based on the findings.

\section{Keywords}

Energy-efficiency innovation; Institutional theory; Regulatory pressures; Social pressures; Institutional division of labor; SMEs. 


\title{
The role of institutional pressures in the introduction of energy-efficiency innovations
}

\begin{abstract}
Relying on the institutional and innovation theories, we argue that the institutional features of countries are significantly influencing energy-efficiency innovation (EEI), a relevant and peculiar type of environmental innovation activities. An analysis of a cross-sectional sample of 22,936 firms from nine European countries, drawn from the 2006-2008 Community Innovation Survey, confirms the hypothesis that formal and informal institutions influence the propensity of firms to introduce EEIs in general. Furthermore, formal institutions that generate regulatory pressures are found to spur both product and process EEI activities, while informal institutions exerting social pressures emerge to be capable of significantly driving only product EEI activities. Large firms appear to be relatively more reactive to high regulatory pressures. We draw implications for policy makers and managers based on the findings.
\end{abstract}

\section{KEYWORDS}

Energy-efficiency innovation; Institutional theory; Regulatory pressures; Social pressures; Institutional division of labor; SMEs. 


\section{INTRODUCTION}

Driven by concerns about environmental degradation and resource depletion, a growing body of research has recently analyzed the barriers and facilitators of innovations that can correct the most detrimental patterns of production and consumption. A major literature stream has explicitly acknowledged the importance of studying the institutional context in order to obtain a better understanding of these dynamics (e.g. Hoffman, 1999), because institutions create incentives for firms and exert pressures on them to perform environmental innovation (EI) activities. Nevertheless, due to the deficiency of meticulous data, only a few studies have made a distinction between different types of EIs (Doran and Ryan, 2016; Ghisetti and Rennings, 2014; Horbach, Rammer, and Rennings, 2012; Veugelers, 2012), and most of them focus on pollution prevention. As a consequence, energy-efficiency innovation, a prominent example of EI, has been understudied in the institutional context. This paper makes advancements in this direction.

The inefficient utilization of energy exhaustible sources and other scarce natural resources is one of the most severe barriers to a sustainable future. Energy is the dominant input of most industrial processes, transportation and, not ultimately, households operations (U.S. Energy Information Administration, 2013). Concerns for the security of supply, climatic changes and noxious emissions motivate the extensive efforts made so far for improving energy efficiency, but entire world regions and several sectors are still lagging behind in the implementation of energy-efficiency patterns (e.g. International Energy Agency, 2016). Consequently there is a need to disentangle the underlying origins of this lag.

Energy-efficiency innovation (EEI) is the activity that leads to the necessary technological change (Bretschger, 2005). We define it as a brand new or significantly improved product or process that uses less energy inputs than alternatives. More generally, EEI is assumed to include invention, deployment and diffusion of technologies that provide more energy services for the same energy input, or the same services for less input. Energy-efficiency innovation is considered to be a type of eco-innovation, that is, a sub-class of environmental innovation that improves not only environmental but also economic performances (Huppes et al., 2008), and hence allows firms to face the potential dual benefit (Rennings and Rammer, 2009). As such, EEI activities are also driven by market-based incentives, as energy-efficient technologies and practices cause a reduction of operational costs i.e. market failure is not as pronounced as for most EIs (Newell, Jaffe, and Stavins, 1999). The link between environmental benefits and economic profit makes it necessary to study this type of innovation separately from other EIs. ${ }^{1}$

The present study focuses on EEI activities at the firm level and adopts an institutional lens of investigation. We argue that the energy efficiency strategies of firms depend on the characteristics of their environment, and inspect how different institutional features shape EEI activities. Other studies have already emphasized the role of demand-pull and technology-push mechanisms for EEIs, such as energy prices, knowledge stocks and stringent standards (Popp, 2002; Verdolini and Galeotti, 2011), but they have disregarded other regulatory, and above all, social features of the complex setting in which firms make decisions about energy efficiency.

\footnotetext{
${ }^{1}$ Admittedly, EIs can also improve economic performance by improving commercial competitiveness, as argued by the Porter hypothesis (Porter and van der Linde, 1995), yet to a lesser extent and with a higher degree of uncertainty than EEIs or eco-innovations (Ekins, 2010). When environmental policies are missing, it is hard for standard financial assessments to justify investments in other EIs (Berrone et al., 2013).
} 
Additionally, we do that in a cross-country setting, which is another aspect that has been overlooked in the hitherto literature (Horbach, Oltra, and Belin, 2013).

The second major contribution of the paper pertains to the distinction between product and process EEIs. Despite the possible interrelatedness of the activities (Bönte and Dienes, 2013), the two EEI types might have both different determinants and implications for companies. This dichotomy has been broadly analyzed in the context of EI in general (e.g. Cleff and Rennings, 1999; Wagner, 2008). For instance, while process EI is found to add very little benefit to the customer and therefore receives comparatively little reward from the market (Cleff and Rennings, 1999), product EI is shown to require greater internal innovation capabilities and external knowledge sources (Horbach et al., 2013). Only a few studies have recognized the importance of such a distinction for EEI (see for example Horbach et al., 2012), yet only in an explorative way. Instead, we offer a theoretical reasoning on why differentiating EEI types is relevant, and how this differentiation can help to have a better understanding of the relationship between institutions and EEI activities.

Third, and equally important, the paper provides a recognition and empirical treatment of the moderating role of the firm characteristics on the relationship between the institutional context and the EEI activities of the firm. The extant research has mostly failed to investigate to what extent different firms respond differently, in terms of EI, to the specific conditions of their institutional context (for the same point see Delmas and Toffel, 2004; del Río, 2009). By performing aggregated analyses, the obtained knowledge has too often painted a onedimensional picture of the subject. However, firms do not respond uniformly to the same level of stakeholder pressures, and corporate environmental strategies seem to vary extensively even within the same industrial sector and the same geographical area (Murillo-Luna, GarcésAyerbe, and Rivera-Torres, 2008; Sprengel and Busch, 2011). The issue was recognized by Berrone et al. (2013), who carried out a detailed analysis on how different institutional pressures cope with different firm-level characteristics in order to explain "green chemistry" innovations. However, they focused on environmental innovations related to pollution prevention. Here, we focus instead on EEIs and study how the relationships between different dimensions of the institutional context and EEIs are moderated by one of its most important characteristics - firm size. In other words, similarly to what del Río, Romero-Jordán, and Peñasco (2017) study in terms of general EI, we investigate the energy-efficiency responses of small and medium enterprises (SMEs) and large incumbent enterprises (LEs). In this way, we address another literature stream and go beyond a commonly used motivation for the observed deficit of EEIs in SMEs, namely the "barriers to innovation" argumentation (Sorrell, Mallett, and Nye, 2011). We posit that, apart from experiencing higher internal or external barriers, SMEs are less responsive to the institutional pressures than LEs. This analysis deserves particular attention because of the high relevance of SMEs in the economic structure of most countries (del Río, 2009).

The developed hypotheses are tested in a cross-country empirical setting using a sample of firms over nine European countries. The pivotal source of the firm-level data is the 2006-2008 Community Innovation Survey, which is supplemented with country level information, sourced from the World Economic Forum, Google Trends, Eurostat, and the World Bank.

\section{THEORETICAL FRAMEWORK}

Different streams of literature have contributed to the development of the institutional theory following the seminal works of North (1990) and Scott (1995). They describe institutions as the "rules of the game", i.e. structures and constraints that shape social behavior. 
The institutional approach complements market characteristics with other formal (e.g. regulations and laws) and informal (e.g. social norms, public opinion, codes of behavior) contextual characteristics (North, 1990); thus emphasizing the importance of regulatory and social pressures rather than mere market institutions in order to understand economic behavior (Chan, Isobe, and Makino, 2008).

The research community has recently shown increased interest in the institutional perspective on EI dynamics and environmental strategies in general. More particularly, the literature has recognized how the institutional context creates incentives and puts pressures on firms that result in a surge of firms' environmental virtuous behavior (Buysse and Verbeke, 2003). These pressures are argued to be channeled through stakeholders that have an interest in the matter and can exert an impact on the firms (Henriques and Sadorsky, 1999; Sharma and Henriques, 2005). However, two points have been overlooked in the extant literature. First, most of the studies have focused on pollution prevention as one type of EIs (Ghisetti and Rennings, 2014; Horbach et al., 2012), neglecting EEIs. Secondly, only few studies have tried to explain EI variations across firms looking at the interactions between the firm characteristics and institutional contextual conditions (Delmas and Toffel, 2010). For instance, Berrone et al. (2013) show that firms with a greater gap in pollution prevention are more exposed to institutional pressures, and that firms' EI strongly depends on the slack in internal resources and the amount of valuable firm-specific assets. Levy and Rothenberg (2002), while analyzing climate change innovation in the global automobile industry, indicate that the institutional context is moderated by firm's boundaries, i.e. each company interprets the institutions through a unique lens, which is shaped by the characteristics of a firm. Literature on corporate social responsibility (CSR), an activity influenced by contextual characteristics and pressures in a similar way to EI (Chatterji and Toffel, 2010), also shows that firm-level characteristics, particularly firm size and the number of customers (Lepoutre and Heene, 2006; Young and Makhija, 2014), moderate the impact of institutional pressures, as they lead to more exposure (Brammer and Millington, 2006).

We argue that the same might hold for EEIs: larger firms could be more reactive to institutional pressures than smaller ones, as smaller businesses might strategically choose to operate in "stealth mode" (Chen and Hambrick, 1995) and remain "under the radar" of their stakeholders. This phenomenon could systematically yield fewer EEI activities in SMEs, and reveal that there is more to it than the "higher barriers to innovate" experienced by smaller firms (see Sorrell et al., 2011), at least in the EEI domain.

\subsection{Formal institutions and energy-efficiency innovation}

Formal institutions, which represent a collection of political, legal and regulatory characteristics of the context, are hypothesized to influence firms to introduce EEIs. Governmental bodies design environmental policies that span a large spectrum of environment conservation mechanisms (Chan et al., 2008). For instance, government expenditures, through subsidies, grants and public procurement measures, allow firms to increase revenues when they engage in EEI activities, making it attracting for firms to invest in EEIs. Governments also set environmental targets and standards that need to be met by the firms. Strict environmental regulations make investments in EEI activities necessary. Nevertheless, apart from the direct compliance with these targets, firms may strategically opt for EEIs that even exceed the standards prescribed by regulators, since "investing-up" may help them establish legitimacy and strengthen a long-term relationship with governments and administrations (Kassinis and Vafeas, 2006). In turn, clear and strict environmental standards and targets can make 
investments in EEI activities not only necessary, but also attractive for firms. On the basis of the aforementioned points, we hypothesize the following:

Hypothesis H1a: EEI activity will be higher in well-developed formal institutional environments.

Notwithstanding this, meeting the requirements of stringent regulations can be a challenging task, and firms that fail to do so might face costly consequences (Deephouse, 1996). The gaps of large firms in EEI will have more eye-catching consequences. Large firms have a larger installed capacity and make a larger use of energy. At the same time, their customers are more numerous and end up utilizing greater quantity of energy. Hence, as key actors, they may be monitored more closely by regulators (Delmas and Toffel, 2004). Owing to the scale of their impact, large firms are subject to potentially more radical sanctions, which increases their incentives to comply with regulations (Berrone et al., 2013). Smaller firms, on the other hand, might be able to strategically shelter themselves from legal coercion, because the impact of their inefficient practices is not as severe. Their smaller scale allows them to evade governmental scrutiny more easily. Moreover, even in the case of government EEI subsidies that have preferential clauses for SMEs given the supposedly higher financial constraints they face (e.g. Beck and Demirguc-Kunt, 2006), large firms may still outdo SMEs, due to the possessed know-how and already welldeveloped R\&D activities. In other words, large firms might be more likely to react with EEIs to regulatory pressures as they have, on average, higher innovation capacity (Tsai and Liao, 2017). Overall, we derive the following hypothesis:

Hypothesis H1b: Larger firms will engage in more EEI activities than smaller firms in well-developed formal institutional environments.

\subsection{Informal institutions and energy-efficiency innovation}

Informal institutions represent those characteristics of the context that are created by the general public, media, nongovernmental organizations (NGOs) and other focal social actors, which determine the so-called social norms (Scott, 1995). These implicit values and conventions affect human behavior within a society, pushing all the actors to behave accordingly (e.g. Chan and Makino, 2007). Like other environmental activities, EEI activities may be under extensive public scrutiny and undergo strong social pressures, due to their great impact on society. According to the stakeholder theory, EEIs may arise from a firm's quest for legitimacy and reputation with social stakeholders (primarily citizens), i.e. assets that are particularly valuable in the long term (Berrone et al., 2013; DiMaggio and Powell, 1983). Firms can gain more from innovations if they adopt strategies that comply with the intrinsic norms and values of their stakeholders (Rao, Chandy, and Prabhu, 2008). Hence, we hypothesize the following:

Hypothesis H2a: EEI activity will be higher in well-developed informal institutional environments.

Nevertheless, in a similar way to regulatory pressures, the exposure of large firms to this social pressure is expected to be greater. As LEs interact with a wider set of stakeholders, they are forced to conduct a more thorough and deliberate assessment of the societal impacts of their activities (Seitanidi and Crane, 2009). On the contrary, SMEs inherently have narrower social 
networks and a smaller customer base. Additionally, the scale of the damage that smaller firms can create is by definition smaller. Key social actors, such as, for instance, NGOs, will presumably assign priorities to putting pressure on large, more impacting firms. Based on the aforementioned factors, we derive the next hypothesis:

Hypothesis $\mathbf{H} \mathbf{2} \boldsymbol{b}$ : Larger firms will engage in more EEI activities than smaller firms in well-developed informal institutional environments.

\subsection{Institutional division of labor and energy-efficiency innovation}

Apart from studying EEIs as a subset of environmental innovation, a further division into product (i.e. more energy-efficient product design) and process (i.e. more energy-efficient design of the production process) innovation can be made, according to the Oslo manual (OECD-Eurostat, 2005). ${ }^{2}$ Though the dynamics of process and product EEIs could partially coincide (Bönte and Dienes, 2013), some differences can also be expected (Gerstlberger, Praest Knudsen, and Stampe, 2014), particularly in the context of stakeholders pressures. Namely, stakeholders are characterized by bounded rationality (à la Simon, 1957), and they do not have infinite resources at their disposal. Accordingly, they can only exert a limited amount of regulatory and social pressures. In doing so, they will rely on consolidated heuristics to guide their behavior and will adhere to a satisfactory criterion rather than an optimal one for their choices (Simon, 1957).

In that vein, the energy-efficiency content of traded products can be monitored and assessed relatively easily, while the comprehension and evaluation of energy uses made during internal production processes are much more difficult. In other words, companies could be reluctantfor strategic reasons - to disclose information about the specific energy efficiency performance of a given production process, and even if they do, this information could be rather cumbersome and costly to understand by non-professional stakeholders. In general, information on production processes may be expected to be underprovided by markets, and this could lead to market failure (Popp, Newell, and Jaffe, 2009). Hence, it can be expected that social stakeholders (e.g. citizens and NGOs) will exert stronger social pressures on firms to introduce product EEIs. Likewise, firms might have greater incentive to introduce EEI products if the customers are able to recognize and appreciate them (similarly to the principal-agent problem mentioned by Popp et al., 2009). On the other hand, information asymmetries between production units and regulators are considerably lower, as the latter can have easier access to the needed information. In order to offset the market failure concerning process EEIs, regulatory bodies have scrutinized them more carefully in the past. These efforts were reflected in command-and-control requirements for process EEIs (such as performance standards or targets), while voluntary agreements, information campaigns and labeling prevailed in product EEI.

Hence, while regulatory and social pressures might still be expected to have a degree of influence on both process and product EEI, we hypothesize that there will be an institutional division of labor between the stakeholders in terms of these two different types of EEIs. ${ }^{3}$ In particular, we posit the following:

\footnotetext{
${ }^{2}$ For illustrative purposes, a well-known example of product EEI is the replacement of incandescent filament light bulbs with Compact Fluorescent Lamps. An example of process EEI is the introduction of a pre-heating stage in furnaces that melt scrap metals.

${ }^{3}$ The institutional division of labor is frequently discussed in the political science field (e.g. Cordelli, 2012), in industrial organization literature (e.g. Richardson, 1972) and in economics in general (e.g. Viscusi, 1988).
} 
Hypothesis H3a: Well-developed formal institutional environment will have a stronger impact on process than on product EEI activities.

Hypothesis H3b: Well-developed informal institutional environment will have a stronger impact on product than on process EEI activities.

\section{DATA AND METHODOLOGY}

A microeconomic perspective is considered and a firm-level analysis is performed across different countries, i.e. across different institutional contexts. The firm-level information is collected from the sixth wave Community Innovation Survey (CIS-VI). The sample spans over the following nine Member States of the European Union (EU): Bulgaria, the Czech Republic, Germany, Hungary, Italy, Lithuania, Portugal, Romania and Slovakia. While we rely on the subset of EU countries that was present in the CIS-VI dataset with complete information on EEI, we believe the heterogeneity of both institutional features and energy-efficiency innovation activity on the national level is sufficiently large in the sample. The variety was accentuated by the fact that during the period of observation (2003-2008) some of the analyzed countries were in a transition phase, both in terms of economic and institutional development. These, in turn, are shown to have had an impact on the countries' energy intensity (e.g. Chang, 2014; Cornillie and Fankhauser, 2004), which is inherently related to EEI.

Specifically, we used the CIS-VI edition as only the 2006-2008 survey was designed to extract precise information about environmental innovation activities (see, e.g., Horbach et al., 2012; Veugelers, 2012). After eliminating observations with key missing values, a final sample of 22,936 was obtained, which includes non-innovative firms, firms that introduced EEIs in the observed period, and firms that undertook only other innovative activities. ${ }^{4}$

\subsection{Measures}

\section{Dependent variable}

In order to study EEI activities at a firm-level, we construct two dependent dichotomous variables that show whether a firm introduced an innovation in the 2006-2008 period that led to reduced energy use per unit of output for the firm (EEIproc) or to more energy-saving products (goods or services) for its customers (EEIprod). Additionally, the EEI variable that accounts for either of the two EEI activities was built. Some authors proposed using information on plans to introduce EEIs in the future to avoid endogeneity (Ziegler and Rennings, 2004), but this could yield measurement problems due to uncertainty about firms actually innovating and response bias related to social desirability (Wagner, 2008).

\section{Explanatory variables}

The key explanatory variables are constructs of different features of the institutional context. To limit possible reverse causality concerns, all the institution-related variables were measured in the period of time immediately preceding the observed EEI timeframe, and are

\footnotetext{
However, it should be remarked that the concept is used in rather different contexts. Our definition is closer to the approach that interprets institutional division of labor as a distribution of functions in the market between public, non-profit and profit agents (e.g. DiMaggio and Anheier, 1990).

${ }^{4}$ The original sample stratification was executed by Eurostat, with respect to firm sector and size (see Eurostat 2008, Table 2).
} 
averaged over time (in the range starting from 2003 or 2004, up to 2005 or 2006, depending on the data availability), with one exception (EnvActivism, for the reasons illustrated in the remaining part of the section).

We use a number of data sources (see Table 1). The stringency of environmental regulations (RegStringency) as well as the clarity and stability of regulations (RegStability) are sourced from the World Economic Forum's (WEF's) Global Competitiveness Reports (GCRs). ${ }^{5}$ More stringent regulations can be expected to exert direct pressure on firms to introduce EEIs, especially in combination with regulation stability, as investments in EEIs are expected to result in long-term returns, and the steadiness of legal framework is a relevant factor (Allard, Martinez, and Williams, 2012). ${ }^{6}$ However, having rigorous and stable regulations may not be enough. The way these legislations are enforced and administered is another important feature. In order to capture the strength of the enforcement mechanism, the measure developed by the World Bank, named "government effectiveness" (GovEffect) is used. Furthermore, data on the governments' environmental protection expenditures (GovEnvExp) are sourced from Eurostat, as a proxy of the governmental support for all environmental activities, including EEIs. The higher the level of available resources, the higher the possibilities for firms to access these resources, and in turn, the higher the expected EEI rate.

The second group of institutional characteristics is related to social norms and pressures created by society, and we represent them using two variables. First, a measure of public attentiveness to environmental issues (PubAttent) is constructed following a novel but increasingly used approach, namely a web-crawling method, which takes advantage of the publicly available Search Volume Index (SVI), created by means of the Google Trends tool (for similar applications see Da Gbadji, Gailly, and Schwienbacher, 2015; Ripberger, 2011). The number of Google web searches of a given term is normalized with respect to the total number of Google searches performed in a country during the specified time period. The measure was built as a relative index, which is coherent with the relative nature of public attentiveness towards one specific concept. We focus on the term "environment", translated into the local languages using the EuroVoc dictionary. ${ }^{7}$ Second, the strength of the mechanism by which the social pressures are transferred to firms (EnvActivism) is taken into account. This strength is proxied by the percentage of active members of voluntary organizations involved in conservation and the environment, as sourced from the European Value Survey (EVS) $2008 .^{8}$ We expect this variable not to be extremely volatile over time, allowing us to use the 2008 measure without a serious risk of reverse causality. The more people in a community have a higher propensity for collective action in the domain of environmental issues, the more intense the institutional pressure they should exert (Delmas and Toffel, 2004; Eesley and Lenox, 2006).

$<<$ Insert Table 1 here $>>$

\footnotetext{
${ }^{5}$ The concept and measures of regulation stringency are topics that have been debated frequently in recent years. For a discussion, see for instance Botta and Kozluk (2014).

${ }^{6}$ The European Commission (2013) found that fast-changing legislation and policies are some of the most severe barriers to SMEs and that they discourage them from undertaking resource saving activities.

${ }^{7}$ The relative attentiveness towards the "environment" is calculated for the 2004-2006 period. As a robustness check, the same variable was constructed focusing on the "energy" term. The alternative indicator is significantly correlated to the original one (correlation coefficient equal to 0.407). EuroVoc is a multilingual thesaurus promoted by the European Union, which contains terms in 23 EU languages.

${ }^{8}$ EVS 2008 is a survey pertaining to human values in Europe. The variable that represents the percentage of people active in voluntary conservation, environment, ecology, and animal rights organizations was used.
} 
In order to confirm the theoretical and intuitive coherence of the variables, and to construct single measures for each institutional dimension, an exploratory factor analysis (EFA) based on principal factor analysis with varimax rotation was used. The results (see Table 2 and the significance of Bartlett's test and the KMO magnitude) confirmed the expectation and yielded two standardized independent variables (iReg and iSoc) that capture the regulatory and social background in which firms are called upon to operate, and proxy regulatory and social pressures that are exerted by these institutions.

$$
<<\text { Insert Table } 2 \text { here }>>
$$

Finally, considering the information contained in the CIS-VI database, firms are differentiated according to two major size categories, namely SMEs (with less than 250 employees) and LEs (with more than or equal to 250 employees). The constructed variable is a dichotomous one $(\boldsymbol{L E})$, and it equals 1 for LEs and 0 for SMEs.

\section{Control variables}

We have firms in the sample that are active beyond the scope of national borders and firms that are a part of a business group, which can have significant impact on the propensity to introduce EEI. Hence, we control for these two firm characteristics using two binary variables (International and Group, respectively). Furthermore, energy price has been widely used in the literature as the main market-based mechanism that induces EEIs (see, among others, Newell et al., 1999; Popp, 2002; Verdolini and Galeotti, 2011), and we control for it in the model. We use electricity price to proxy energy price $(\boldsymbol{E P})$ by taking information from the dataset on international industrial energy prices prepared by the UK's Department for Business, Energy and Industrial Strategy, and averaging it over the 2003-2005 period. The electricity prices are referred to, since electricity is the most commonly used energy source in most households and industries. The selected proxy accounts for differences in electricity prices between business enterprises located in the same country but belonging to different consumption classes, as the electricity price varies across consumption levels within single EU countries. In turn, $\boldsymbol{E P}$ is an indicator that differs between small and medium, and large consumers in each EU country. ${ }^{9}$ We also control for the firm's R\&D intensity, namely, the percentage of $R \& D$ expenditures with respect to the firm's turnover ( $\boldsymbol{R} \boldsymbol{D}$, source: CIS-VI). Finally, the margin for energy-efficiency improvements, and thus, for EEIs is considerably heterogeneous across different industries. Therefore, we control for the firm industry through a set of dummy variables.

The definitions of the variables are summarized in Table 3, while their correlation and descriptive statistics are presented in Table 4. Table 5 reports the distribution of innovating firms in all EEI domains and segmented for size class across the nine countries of our sample.

$<<$ Insert Table 3, Table 4 and Table 5 here $>>$

\subsection{Model specification}

Given the dichotomous nature of the main dependent variable (EEI), we initially estimate univariate probit models. In order to test the third set of hypotheses, we additionally estimate bivariate probit models following the suggestion of Greene (2003) and Wagner (2007, 2008),

\footnotetext{
${ }^{9}$ We also test an alternative country-aggregate proxy of electricity price (EPCountry, sourced from Eurostat). The obtained results are virtually unchanged and are available upon request from the authors.
} 
as the two dependent variables (EEIprod and EEIproc) are correlated. ${ }^{10}$ Standard errors always allow for intra-country correlation.

Two full models’ specifications are given by Equations (1):

$$
\begin{gathered}
E E I_{\text {type }}=\alpha+\beta_{1} \cdot \text { iReg }+\beta_{2} \cdot i S o c+\beta_{3} \cdot L E+\beta_{4} \cdot i R e g \cdot L E+\beta_{5} \cdot i S o c \cdot L E+\beta_{6} \cdot \text { International }+ \\
\beta_{7} \cdot \text { Group }+\beta_{8} \cdot \text { EPrice }+\beta_{9} \cdot R \& D+\bar{\beta}_{10} \cdot \text { DSectors }+\epsilon,
\end{gathered}
$$

where type captures the different typologies of EEI (product, process, either). Owing to the non-linear nature of the models, interaction terms introduce additional degrees of complexity in the interpretation of the results. Hence, we estimate the marginal effects of the two-way interactions in different ways (see infra), mainly following Hoetker (2007).

\section{RESULTS}

\subsection{Main analysis}

Table 6 presents the main estimation results. The first column refers to the results of the model with direct effects only (Model 1a). Both types of institutional pressures, iReg and iSoc, created by formal and informal institutions respectively, appear to influence EEI activities positively and significantly (at 1 percent and 10 percent levels, respectively), thus supporting hypotheses $\mathbf{H 1 a}$ and $\boldsymbol{H} 2 \boldsymbol{a}$. As expected, firm size, R\&D intensity and energy price all emerge as having a positive impact. ${ }^{11}$ As far as the results of the model that also includes the two-way effects (Model 1b), the baseline coefficients essentially do not change, which validates the model specifications. More interestingly, the interaction between formal institutions and firm size also emerges to have a significant impact (at 1 percent level). On the contrary, firm size does not appear to significantly moderate the effect of informal institutions on EEIs. Overall, these results suggest confirmation of $\boldsymbol{H 1 b}$ hypothesis and provide no evidence in support of the $\boldsymbol{H} \mathbf{2} \boldsymbol{b}$ hypothesis.

$$
<<\text { Insert Table } 6 \text { here }>>
$$

We also analyze the marginal effects of the two-way interaction terms. As it is not possible to uniquely express the marginal effect of an interacting variable in non-linear models (Buis 2010; Ai and Norton, 2003), we estimate the effect of a moderator (i.e. firm size) visually (see Figure 1). Interesting results emerge - namely, the difference between the impact formal institutions exhibit on SMEs and LEs is observable only in relatively weak formal institutional environments, while the difference ceases in relatively stronger ones. On the contrary, as predicted by the significance level of the interaction term coefficient, informal institutions appear to have no different impact on SMEs and LEs in terms of EEI activity over the whole range.

$$
<<\text { Insert Figure } 1 \text { here }>>
$$

\footnotetext{
${ }^{10}$ The bivariate probit model is a more appropriate choice than a multinomial logit model, because the two outcomes, i.e. product and process EEIs, cannot be assumed to be independent. However, as a robustness check, a multinomial logit model, similar to that of Rehfeld, Rennings, and Ziegler (2007) was run, and comparable results were obtained.

11 The coefficients of industry dummies are in line with expectations: they are positive for manufacturing industries with more energy intensive processes and products, while they are negative for services industries, although they are mostly statistically non-significant ( $p$-value is greater than 0.2 ).
} 
The remaining four columns in Table 6 show the estimation results of the bivariate probit models with direct effects only (Models 2a and 2b) and when the two-way effects are added (Models 3a and 3b). As far as regulatory pressures are concerned, the results show that they significantly drive both product and process EEI. Moreover, Wald test yields no statistically significant difference between the impacts of the formal institutions on the two types of EEI (Prob $>$ chi2=0.4825). Even though the impact of regulatory pressures on process EEI is undeniable (and more so on large firms, see Figure 2), the obtained result does not provide support for hypothesis $\mathbf{H 3 a}$. On the other hand, as we hypothesized $(\boldsymbol{H} 3 \boldsymbol{b})$, social pressures appear to predominantly influence product EEI. Coefficient of informal institutions is statistically significant (at 1 percent level) only in the product EEI model and non-significant in the process EEI one. Moreover, a Wald test confirms a statistically significant difference between the two coefficients (Prob $>$ chi2 $=0.0057$ ).

\section{$<<$ Insert Figure 2 here $>>$}

Additionally, we carry out a simulation analysis to gain further insights into the effect the institutional pressures have on the different types of EEIs, while keeping the control variables at their mean values. After fixing the value of one institutional variable to its minimum and maximum, the other institutional variable was varied. The institutional pressures are confirmed to be complementary to each other (and not substitutive), because EEI activities (and more particularly, product EEI activities) reach the maximum probability only under the hypothetical scenario in which both institutional pressures are set to their maximum value - EEI probability takes on a value of 0.60 (and 0.52 for product EEI). Finally, under this hypothetical scenario, EEI (as well as product EEI) probability is considerably higher for LEs (0.76 and 0.61 for product EEE) than for SMEs (0.57 and 0.51 for product EEI).

\subsection{Robustness checks and additional evidence}

We performed several tests on the reliability of these findings. All results are available in detail upon request from the authors. First, the potential multicollinearity of the main independent variables was checked by running a Variance Inflation Factor (VIF) test. The resulting mean VIF value is fairly low (1.18), thus confirming that the analysis has not been hindered statistically in the proposed model specification. We also checked in three ways whether the observed results are driven by differences in the overall level of innovativeness or development between the included countries. We regressed explanatory variables on a dichotomous innovation variable, $\boldsymbol{I}$, set equal to 1 if a firm introduced any type of innovation in the time window under consideration, and the coefficients of the institutional variables resulted to be not highly statistically significant. This finding further supports the rationale that the institutional dimensions under scrutiny are not a generic indication of a country's progress, but that they are specifically relevant for EEIs. In this line of investigation, we also inserted as a further independent variable the covariate $\boldsymbol{P I}$, which represents the percentage of firms that introduced any type of innovation (that is, not only EEI) in the same timeframe, in the same industry, country and size class of the focal firm. The results were found to be largely unaffected by the insertion of this variable, that is, the findings on the role of institutions and firm size on EEI activities are not driven by specific unobserved and uncontrolled characteristics of the technological regime on which firms are called to operate (del Río et al., 2015). Moreover, the analysis was repeated excluding each country at a time, one by one, and the results emerged to be consistent. In this way, the possibility of the results being dominated by one of the sample countries has been ruled out.

Furthermore, we repeated the full analysis on a subsample of firms that did not include internationally active companies and firms that are a part of a business group, in order to isolate 
the effect of national institutional environment, which we are able to capture. Most findings are robust to the sample restriction, while pressures created by social stakeholders on process EEI become more statistically significant. A possible explanation could be that the exclusively national firms may not be as capable of evading the local pressures as the internationally active ones (and the firms that are a part of a business group).

Finally, we performed a sensitivity analysis on the $\boldsymbol{L} \boldsymbol{E}$ variable. The firms were re-classified into three groups, namely small enterprises (SEs, with less than 50 employees), medium enterprises (MEs, with between 50 and 249 employees), and large enterprises (LEs, with more than or a number equal to 250 employees). We found the results (exposed in Table 7) to be generally coherent and robust. Moreover, based on these findings, we confirm that MEs react more closely to LEs to both regulatory and social pressures.

$$
<<\text { Insert Table } 7 \text { here }>>
$$

We also followed the recommendations of Hoetker (2007) on the analysis of marginal effects of interaction effects in probit models. Specifically, we first run an Allison's test (Allison, 1999), which yields to be negative. Thus, we performed the procedure suggested by $\mathrm{Ai}$ and Norton (2003), who provided an alternative technique to calculate the marginal effects of an interaction term in non-linear models. The results are found to be coherent with the findings reported in the main analysis.

\section{DISCUSSION AND CONCLUSIONS}

This study establishes a link between several literature streams-institutional theories of corporate strategies, environmental innovation and energy efficiency — and uses the hybrid approach to discover whether and to what extent different characteristics of the institutional context can influence a firm's propensity to introduce EEIs. In this way, firm size has been taken into consideration as a possible moderating factor of the relationship between institutions and EEIs, and different EEI types have been distinguished, i.e. product vs. process. The results of the empirical analysis confirm that institutional pressures are relevant for EEI activities, and large firms are on average relatively more sensitive to regulatory pressures while not to social pressures. More interestingly, further differences between types of institutional pressures arise when a distinction between product and process EEIs is made. On the one hand, social stakeholders seem to be more successful in putting pressure on firms to introduce product EEIs. Several arguments support this idea. First, the increasing attentiveness towards environmental issues is creating a demand-pull mechanism for more energy efficient products, as the customers that will potentially consume them are part of that community. Second, the community is creating pressures on firms to be more environment-friendly, and firms are inclined to comply with the community's opinion in order to earn its legitimacy (Reid and Toffel, 2009). The fact that social pressures are not able to influence process EEIs, particularly for the incumbent firms, may be also due to institutional strategies that the firms can use to shield themselves from the pressures of external stakeholders (Smink, Hekkert, and Negro, 2015). On the contrary, we find that regulatory stakeholders appear to be capable of exerting pressures on firms to introduce innovations in the energy efficiency of both products and production processes. Their impact on large firms (when compared to the smaller ones) is even more prominent. This can be explained by the fact that European governments have only recently started to adopt a combined vertical approach by targeting EEIs in small and medium 
firms (Trianni and Cagno, 2012), ${ }^{12}$ which are the economic actors that usually suffer from higher constraints. Nonetheless, this effect disappears once the formal institutions become highly developed.

Our study has several limitations that remain to be addressed in future research. First, the sample could be enlarged to cover a larger set of countries, and in particular developing ones. Their inclusion would increase the variance of the institutional context in the analysis, and could make the findings more robust. Second, due to anonymous nature of CIS-VI data, it is currently not possible to delve deeper into the firm size variable and study micro-level factors in more detail. This avenue would be able to provide interesting insights related to the other firm-level variables that could be relevant for EEI. Third, the present analysis is not able to take into account that some of the firms are active internationally due to data limits found in the CIS-VI dataset. This issue is a caveat, but also represents an opportunity for future research, which could highlight the influence of multiple institutional contexts at the same time. Finally, it has been necessary to use cross-sectional data in the analyses, and this has made it impossible to capture the temporal dynamics of the relationship between institutions and EEI activities. In particular, it has not been possible to account for the potentially different initial energyefficiency conditions of firms. Although there is no reason to believe this would substantially change the findings, a panel data structure would enable this aspect to be examined explicitly.

Despite these unavoidable data limitations, we believe that our study offers insights into the general domain of the stakeholder theory and the natural environment, and proposes a possible explanation that could help reconcile the mixed results of the studies in the field. In fact, some analyses (e.g. Murillo-Luna et al., 2008; Sprengel and Busch, 2011) have suggested that firms adopt their corporate environmental strategies on the basis of the overall level of pressure they perceive, while they are not very concerned with identifying the source of these pressures; others instead have pointed out that the typologies of pressure matter (e.g. Berrone et al., 2013; Sharma and Henriques, 2005). Our theoretical reasoning and the acquired empirical evidence show that a reconciling view is possible as long as different types of ecoinnovations are considered. In other words, our analysis is compatible with a more nuanced picture in which firms tailor their corporate environmental behavior according to the overall pressure they perceive, but then differentiate the direction of the planned innovative effort towards those types of eco-innovations (e.g. product vs. process) in which the pressure is more stringent. These findings are more pronounced for large firms, implying that their managers carefully analyze the source of pressures, and act accordingly. Similarly to the work of Berrone et al. (2013), our findings thus suggest that institutional pressures, as they create incentives for eco-innovative activities, may also influence allocation of internal resources into R\&D and development of unique know-how, which may be leveraged by the organization in other activities as well (Porter and van der Linde, 1995).

Our findings also add to the dialogue on the power and effectiveness of governments to promote more sustainable activities, and in turn, more resource-efficient outcomes. First, we show that the efforts of regulators are more effective for large firms. Hence, energy-efficiency innovation policies should be rebalanced towards EEIs in smaller firms (Costa-Campi, GarcíaQuevedo, and Segarra, 2015; Trianni and Cagno, 2012). Simultaneously, governments could enhance the monitoring of energy-efficiency in SMEs, also thanks to technological developments (for instance, by means of smart metering). Second, policymakers should be aware of the fact that, in some cases, remedies have to go beyond classical policies. Voluntary

\footnotetext{
12 The International Energy Agency (2014) states that data collection related to energy consumption by SMEs is not a generalized practice and that no underlying legislation for mandatory reporting exists in many countries, despite the great contribution of SMEs to the total energy consumption.
} 
agreements of industries toward energy-efficient products already leverage society's stewardship, but the degree to which public policies can combine with and support citizens' attention and activism is the subject of a wide debate (e.g. Doh and Guay, 2006; Sprengel and Busch, 2011), which still has to be fully developed with respect to EEIs. However, in principle, the need to complement the reduced degree of social pressure on process EEIs perceived by firms with policy actions could take on several forms, ranging from soft instruments (e.g. promotional campaigns, information and voluntary programs) to more structured ones, such as financial incentives for consumer purchases, income tax credits or deductions of products created by more energy-efficient processes (Gillingham, Newell, and Palmer, 2006). 


\section{REFERENCES}

Ai C, Norton E. 2003. Interaction terms in logit and probit models. Economics Letters 80(1): 123-129. Available

at: http://www.sciencedirect.com/science/article/pii/S0165176503000326.

Allard G, Martinez CA, Williams C. 2012. Political instability, pro-business market reforms and their impacts on national systems of innovation. Research Policy. Elsevier B.V. 41(3): 638-651. Available at: http://linkinghub.elsevier.com/retrieve/pii/S0048733311002277.

Allison PD. 1999. Comparing Logit and Probit Coefficients Across Groups. Sociological Methods \& Research 28(2): 186-208.

Beck T, Demirguc-Kunt A. 2006. Small and medium-size enterprises: Access to finance as a growth constraint. Journal of Banking \& Finance 30(11): 2931-2943. Available at: http://linkinghub.elsevier.com/retrieve/pii/S0378426606000926.

Berrone P, Fosfuri A, Gelabert L, Gomez-Mejia LR. 2013. Necessity as the mother of 'green' inventions: Institutional pressures and environmental innovations. Strategic Management Journal 34(8): 891-909. Available at: http://onlinelibrary.wiley.com/doi/10.1002/smj.2041/full.

Bönte W, Dienes C. 2013. Environmental Innovations and Strategies for the Development of New Production Technologies: Empirical Evidence from Europe. Business Strategy and the Environment 22(8): 501-516. Available at: 10.1002/bse.1753\%5Cnhttp://search.ebscohost.com/login.aspx?direct=true\&db=bth\&A $\mathrm{N}=93278382 \&$ site $=$ ehost-live.

Botta E, Kozluk T. 2014. Measuring Environmental Policy Stringency in OECD Countries - A Composite Index Approach. OECD Environmental Directorate Working Paper, OECD Environmental Directorate Working Paper. Paris, France.

Brammer S, Millington A. 2006. Firm size, organizational visibility and corporate philanthropy: an empirical analysis. Business Ethics: A European Review 15(1): 6-18.

Bretschger L. 2005. Economics of technological change and the natural environment: How effective are innovations as a remedy for resource scarcity? Ecological Economics 54(23): 148-163. Available at: http://linkinghub.elsevier.com/retrieve/pii/S0921800905000297.

Buis ML. 2010. Stata tip 87: Interpretation of interactions in nonlinear models. The Stata Journal 10(2): 305-308.

Buysse K, Verbeke A. 2003. Proactive Environmental Strategies: A Stakeholder Management Perspective. Strategic Management Journal 24(5): 453-470. Available at: http://onlinelibrary.wiley.com/doi/10.1002/smj.299/abstract.

Chan CM, Isobe T, Makino S. 2008. Which country matters? Institutional development and foreign affiliate performance. Strategic Management Journal 29(11): 1179-1205.

Chan CM, Makino S. 2007. Legitimacy and multi-level institutional environments: implications for foreign subsidiary ownership structure. Journal of International Business Studies 38(4): 621-638. Available at: http://www.palgravejournals.com/doifinder/10.1057/palgrave.jibs.8400283.

Chang M. 2014. Energy intensity, target level of energy intensity, and room for improvement in energy intensity: An application to the study of regions in the EU. Energy Policy. Elsevier 67: 648-655. Available at: http://dx.doi.org/10.1016/j.enpol.2013.11.051.

Chatterji A, Toffel M. 2010. How firms respond to being rated. Strategic Management Journal 31(9): 917-945. Available at: http://onlinelibrary.wiley.com/doi/10.1002/smj.840/full.

Chen M-J, Hambrick DC. 1995. Speed, Stealth, and Selective Attack: How Small Firms Differ from Large Firms in Competitive Behavior. Academy of Management Journal 38(2): 453482. 
Cleff T, Rennings K. 1999. Determinants of environmental product and process innovation. European Environment 9(5): 191-201. Available at: http://dx.doi.org/10.1002/(SICI)1099-0976(199909/10)9:5\%3C191::AIDEET201\%3E3.0.CO;2-M.

Cordelli C. 2012. The Institutional Division of Labor and the Egalitarian Obligations of Nonprofits. Journal of Political Philosophy 20(2): 131-155.

Cornillie J, Fankhauser S. 2004. The energy intensity of transition countries. Energy Economics 26(3): 283-295.

Costa-Campi MT, García-Quevedo J, Segarra A. 2015. Energy efficiency determinants: An empirical analysis of Spanish innovative firms. Energy Policy 83: 229-239.

Deephouse DL. 1996. Does Isomorphism Legitimate? Academy of Management Journal 39(4): 1024-1039.

Delmas MA, Toffel MW. 2004. Stakeholders and environmental management practices: an institutional framework. Business Strategy and the Environment 13(4): 209-222.

Delmas MA, Toffel MW. 2010. Institutional Pressures and Organizational Characteristics: Implications for Environmental Strategy. Harvard Business School Working Paper. Cambridge, MA.

DiMaggio PJ, Anheier HK. 1990. The Sociology of Nonprofit Organizations. Annual Review of Sociology 16(1990): 137-159.

DiMaggio PJ, Powell WW. 1983. The Iron Cage Revisited: Institutional Isomorphism and Collective Rationality in Organizational Fields. American Sociological Review 48(2): 147-160.

Doh J, Guay T. 2006. Corporate Social Responsibility , Public Policy , and NGO Activism in Europe and the United States: An Institutional-Stakeholder Perspective. Journal of Management Studies 43(1): 47-73. Available at: http://onlinelibrary.wiley.com/doi/10.1111/j.1467-6486.2006.00582.x/full.

Doran J, Ryan G. 2016. The Importance of the Diverse Drivers and Types of Environmental Innovation for Firm Performance. Business Strategy and the Environment 25(2): 102119.

Eesley C, Lenox MJ. 2006. Firm responses to secondary stakeholder action. Strategic Management Journal 27(8): 765-781. Available at: http://doi.wiley.com/10.1002/smj.536.

Ekins P. 2010. Eco-innovation for environmental sustainability: concepts, progress and policies. International Economics and Economic Policy 7(2-3): 267-290. Available at: http://link.springer.com/10.1007/s10368-010-0162-z.

European Commission. 2013. Spotlight on European public opinion in 2013 - A Eurobarometer Almanac. Brussels, Belgium.

Eurostat. 2008. Community Innovation Survey 2008 Synthesis Quality Report. Brussels, Belgium.

Da Gbadji LAG, Gailly B, Schwienbacher A. 2015. International Analysis of Venture Capital Programs of Large Corporations and Financial Institutions. Entrepreneurship Theory and Practice, CRECIS Working Paper. Leuven, Belgium 39(5): 1213-1245. Available at: http://doi.wiley.com/10.1111/etap.12105.

Gerstlberger W, Praest Knudsen M, Stampe I. 2014. Sustainable Development Strategies for Product Innovation and Energy Efficiency. Business Strategy and the Environment 23(July 2013): 131-144. Available at: http://www.scopus.com/inward/record.url?eid=2s2.0-84894249931\&partnerID=tZOtx3y1.

Ghisetti C, Rennings K. 2014. Environmental innovations and profitability: How does it pay to be green? An empirical analysis on the German innovation survey. Journal of Cleaner Production. Elsevier Ltd 75: 106-117. Available at: 
http://dx.doi.org/10.1016/j.jclepro.2014.03.097.

Gillingham K, Newell R, Palmer K. 2006. Energy Efficiency Policies: A Retrospective Examination. Annual Review of Environment and Resources 31(1): 161-192. Available at: http://www.annualreviews.org/doi/abs/10.1146/annurev.energy.31.020105.100157.

Greene WH. 2003. Econometric analysis, 5th ed. Pearson Education: Englewood Cliffs, NJ.

Henriques I, Sadorsky P. 1999. The Relationship Between Environmental Commitment and Managerial Perceptions of Stakeholder Importance. Academy of Management Journal 42(1): 87-99.

Hoetker G. 2007. The Use of Logit and Probit Models in Strategic Management Research: Critical Issues. Strategic Management Journal 28(4): 331-343.

Hoffman AJ. 1999. Institutional Evolution and Change: Environmentalism and the U.S. Chemical Industry. Academy of Management Journal 42(4): 351-371.

Horbach J, Oltra V, Belin J. 2013. Determinants and Specificities of Eco-Innovations Compared to Other Innovations-An Econometric Analysis for the French and German Industry Based on the Community Innovation Survey. Industry \& Innovation 20(6): 523543. Available at: http://www.tandfonline.com/doi/abs/10.1080/13662716.2013.833375.

Horbach J, Rammer C, Rennings K. 2012. Determinants of eco-innovations by type of environmental impact-The role of regulatory push/pull, technology push and market pull. Ecological Economics 78(11): 112-122. Available at: http://www.sciencedirect.com/science/article/pii/S0921800912001358.

Huppes $\mathrm{G}$ et al. 2008. Measuring eco-innovation: framework and typology of indicators based on causal chains. ECODRIVE Report to the European Commission.

International Energy Agency. 2014. Energy Efficiency Indicators: Essentials for Policy Making. Paris, France.

International Energy Agency. 2016. Energy Efficiency Market Report 2016. Paris, France. Available

at:

www.1e.com/energycampaign/.../Server_Energy_and_Efficiency_Report_2009.pdf.

Kassinis G, Vafeas N. 2006. Stakeholder pressures and environmental performance. Academy of Management Journal 49(1): 145-159. Available at: http://amj.aom.org/content/49/1/145.short.

Lepoutre J, Heene A. 2006. Investigating the Impact of Firm Size on Small Business Social Responsibility: A Critical Review. Journal of Business Ethics 67(3): 257-273. Available at: http://link.springer.com/10.1007/s10551-006-9183-5.

Levy D, Rothenberg S. 2002. Heterogeneity and change in environmental strategy: technological and political responses to climate change in the global automobile industry. In Organizations, Policy and the Natural Environment: Institutional and Strategic Perspectives, Hoffman AJ, Ventresca MJ (eds). Stanford University Press: Stanford, CA: 173-193.

Murillo-Luna JL, Garcés-Ayerbe C, Rivera-Torres P. 2008. Why do patterns of environmental response differ? A stakeholders' pressure approach. Strategic Management Journal 29(11): 1225-1240. Available at: http://doi.wiley.com/10.1002/smj.711.

Newell RG, Jaffe AB, Stavins RN. 1999. The induced innovation hypothesis and energy-saving technological change. The Quarterly Journal of Economics 114(3): 941-975. Available at: http://qje.oxfordjournals.org/content/114/3/941.short.

North DC. 1990. Institutions, Institutional Change and Economic Performance. Cambridge University Press: Cambridge, UK.

OECD-Eurostat. 2005. Oslo Manual, 3rd ed. OECD Publishing: Paris, France. Available at: http://scholar.google.com/scholar?hl=en\&btnG=Search\&q=intitle:Oslo+Manual\#0.

Popp D. 2002. Induced Innovation and Energy Prices. American Economic Review 92(1): 160180. Available at: http://www.nber.org/papers/w8284. 
Popp D, Newell RG, Jaffe AB. 2009. Energy, the environment, and technological change. NBER Working Paper, NBER Working Paper. Cambridge, MA. Available at: http://www.nber.org/papers/w14832.

Porter M, van der Linde C. 1995. Green and Competitive: Ending the Stalemate. Harvard Business Review : 119-134. Available at: http://ww2.ie.ufrj.br/hpp/intranet/pdfs/artigo_porter_linde_thegreenadvantage_1995.pdf.

Rao RS, Chandy RK, Prabhu JC. 2008. The Fruits of Legitimacy: Why Some New Ventures Gain More from Innovation Than Others. Journal of Marketing. American Marketing Association 72(4): 58-75. Available at: http://dx.doi.org/10.1509/jmkg.72.4.58.

Rehfeld K-M, Rennings K, Ziegler A. 2007. Integrated product policy and environmental product innovations: An empirical analysis. Ecological Economics 61(1): 91-100. Available at: http://linkinghub.elsevier.com/retrieve/pii/S0921800906000814.

Reid EM, Toffel MW. 2009. Responding to public and private politics: Corporate disclosure of climate change strategies. Strategic Management Journal 30(11): 1157-1178.

Rennings K, Rammer C. 2009. Increasing energy and resource efficiency through innovationan explorative analysis using innovation survey data. Czech Journal of Economics and Finance, ZEW - Centre for European Economic Research Discussion 59(5): 442-459. Available at: http://papers.ssrn.com/sol3/Delivery.cfm?abstractid=1495761.

Richardson GB. 1972. The organisation of industry. The Economic Journal 82(327): 883-896. del Río P. 2009. The empirical analysis of the determinants for environmental technological change: A research agenda. Ecological Economics. Elsevier B.V. 68(3): 861-878. Available at: http://linkinghub.elsevier.com/retrieve/pii/S0921800908003030.

del Río P, Peñasco C, Romero-Jordán D. 2015. Distinctive Features of Environmental Innovators: An Econometric Analysis. Business Strategy and the Environment 24(6): 361-385. Available at: http://doi.wiley.com/10.1002/bse.1822.

del Río P, Romero-Jordán D, Peñasco C. 2017. Analysing firm-specific and type-specific determinants of eco-innovation. Technological and Economic Development of Economy 23(2): 270-295. Available at: https://www.tandfonline.com/doi/full/10.3846/20294913.2015.1072749.

Ripberger J. 2011. Capturing Curiosity Using Internet Search Trends to Measure Public Attentiveness. Policy Studies Journal 39(2): 239-260. Available at: http://onlinelibrary.wiley.com/doi/10.1111/j.1541-0072.2011.00406.x/full.

Scott WR. 1995. Institutions and organizations, 3rd ed. Sage: Thousand Oaks, CA.

Seitanidi M, Crane A. 2009. Implementing CSR Through Partnerships: Understanding the Selection, Design and Institutionalisation of Nonprofit-Business Partnerships. Journal of Business Ethics. Springer Netherlands 85(2): 413-429. Available at: http://dx.doi.org/10.1007/s10551-008-9743-y.

Sharma S, Henriques I. 2005. Stakeholder Influences on Sustainability Practices in the Canadian Forest Products Industry. Strategic Management Journal 26: 159-180.

Simon HA. 1957. A Behavioral Model of Rational Choice. In Models of Man, Social and Rational: Mathematical Essays on Rational Human Behavior in a Social Setting. Willey: New York City, NY.

Smink MM, Hekkert MP, Negro SO. 2015. Keeping sustainable innovation on a leash? Exploring incumbents' institutional strategies. Business Strategy and the Environment 24(2): 86-101.

Sorrell S, Mallett A, Nye S. 2011. Barriers to industrial energy efficiency: a literature review. Development Policy, Statistics and Resaeerch Branch Working Papers, Development Policy, Statistics and Resaeerch Branch Working Papers. Vienna, Austria.

Sprengel DC, Busch T. 2011. Stakeholder engagement and environmental strategy - the case of climate change. Business Strategy and the Environment 20(6): 351-364. Available at: 
http://dx.doi.org/10.1002/bse.684.

Trianni A, Cagno E. 2012. Dealing with barriers to energy efficiency and SMEs: Some empirical evidences. Energy. Elsevier Ltd 37(1): 494-504. Available at: http://linkinghub.elsevier.com/retrieve/pii/S0360544211007237.

Tsai KH, Liao YC. 2017. Innovation Capacity and the Implementation of Eco-innovation: Toward a Contingency Perspective. Business Strategy and the Environment 26(7): 10001013.

U.S. Energy Information Administration. 2013. International Energy Outlook 2013. Washington, DC.

Verdolini E, Galeotti M. 2011. At home and abroad: An empirical analysis of innovation and diffusion in energy technologies. Journal of Environmental Economics and Management. Elsevier 61(2): 119-134. Available at: http://linkinghub.elsevier.com/retrieve/pii/S0095069610001233.

Veugelers R. 2012. Which policy instruments to induce clean innovating? Research Policy. Elsevier B.V. 41(10): 1770-1778. Available at: http://linkinghub.elsevier.com/retrieve/pii/S0048733312002156.

Viscusi WK. 1988. Product Liability and Regulation: Establishing the Appropriate Institutional Division of Labor. American Economic Review 78(2): 300-304. Available at: http://search.ebscohost.com/login.aspx?direct=true\&db=bth\&AN=4506627\&site=ehostlive\&scope $=$ site.

Wagner M. 2007. On the Relationship Between Environmental Management, Environmental Innovation and Patenting: Evidence from German Manufacturing Firms. Research Policy 36: 1587-1602.

Wagner M. 2008. Empirical influence of environmental management on innovation: Evidence from Europe. Ecological Economics 66(2-3): 392-402. Available at: http://www.sciencedirect.com/science/article/pii/S0921800907005010.

Young SL, Makhija M V. 2014. Firms’ corporate social responsibility behavior: An integration of institutional and profit maximization approaches. Journal of International Business Studies. Nature Publishing Group 45(6): 670-698. Available at: http://www.palgravejournals.com/doifinder/10.1057/jibs.2014.29.

Ziegler A, Rennings K. 2004. Determinants of Environmental Innovations in Germany: Do Organizational Measures Matter? A Discrete Choice Analysis at the Firm Level. ZEW Discussion Papers, ZEW Discussion Papers. Mannheim, Germany. 


\section{TABLES}

Table 1. Description of the variables that characterize the institutional context.

\begin{tabular}{l|l}
\hline Variable & Description \\
\hline RegStringency & $\begin{array}{l}\text { Stringency of environmental regulations in the 2003-2005 period in a country [scale 1-7] } \\
\text { (source: Global Competitiveness Reports 2003/2004-2005/2006, the World Economic } \\
\text { Forum). } \\
\text { Clarity and stability of regulations in the 2003-2005 period in a country [scale 1-7] (source: } \\
\text { Global Competitiveness Reports 2003/2004-2005/2006, the World Economic Forum). } \\
\text { Index that measures the quality of public services, the quality of the civil service and the } \\
\text { degree of its independence from political pressures, the quality of policy formulation and } \\
\text { implementation, and the credibility of the government's commitment to such policies in the } \\
\text { 2003-2005 period in a country [scale 0-100] (source: the Worldwide Governance Indicators } \\
\text { (WGI), the World Bank). } \\
\text { Average annual environmental protection expenditures information of a government [Euros } \\
\text { per capita] in the 2003-2005 period (source: the Environmental protection expenditure, } \\
\text { Eurostat). } \\
\text { Index that measures public attentiveness towards energy in the 2004-2006 period in a country } \\
\text { (source: Google Trends). } \\
\text { Percentage of adults in a country actively participating in voluntary organizations involved in } \\
\text { solving problems related to conservation, the environment, the ecology and animal rights } \\
\text { (source: the fourth wave of European Value Survey 2008). }\end{array}$ \\
\hline
\end{tabular}

Table 2. Output of the exploratory factor analysis (orthogonal varimax rotated factor matrix) of the items used to construct the relevant institutional context for energy-efficiency innovation.

\begin{tabular}{l|cc}
\hline Variable & iReg & iSoc \\
\hline RegStringency & 0.9834 & \\
RegStability & 0.9680 & \\
GovEffect & 0.9559 & \\
GovEnvExp & 0.5505 & 0.8411 \\
PubAttent & & 0.8562 \\
EnvActivism & 0.8975 & 0.6465 \\
\hline Cronbach's alpha & & \\
\hline Notes: Kaiser-Meyer-Olkin measure (KMO) $=0.584 ;$ Bartlett's \\
p<0.001; the cut-off value was set to 0.5.
\end{tabular}


Table 3. Description of the variables used in the econometric analysis.

\begin{tabular}{|c|c|}
\hline Variable & Description \\
\hline EEIprod & $\begin{array}{l}\text { Dichotomous variable that accounts for product energy-efficient innovation of a firm in the } \\
2006-2008 \text { period [" } 1 \text { ": Introduced product energy-efficient innovation, "0": Did not } \\
\text { introduce product energy-efficient innovation] (source: CIS-VI dataset). }\end{array}$ \\
\hline EEIproc & $\begin{array}{l}\text { Dichotomous variable that accounts for process energy-efficient innovation of a firm in the } \\
2006-2008 \text { period [" } 1 \text { ": Introduced process energy-efficient innovation, "0": Did not } \\
\text { introduce process energy-efficient innovation] (source: CIS-VI dataset). }\end{array}$ \\
\hline$E E I$ & $\begin{array}{l}\text { Dichotomous variable that accounts for either product or process energy-efficient innovation } \\
\text { of a firm in the } 2006-2008 \text { period [" } 1 \text { ": Introduced energy-efficient innovation, " } 0 \text { ": Did not } \\
\text { introduce energy-efficient innovation] (source: CIS-VI dataset). }\end{array}$ \\
\hline iReg & Formal institutional variable; standardised $($ mean $=0$, st.d. $=1)$ \\
\hline isoc & Informal institutional variable; standardised $($ mean $=0$, st.d. $=1)$ \\
\hline$L E$ & $\begin{array}{l}\text { Dichotomous variable that accounts for the firm size ["0": "SME ( }<250 \text { employees)", "1": } \\
\text { "LE ( }>-250 \text { employees)"] (source: CIS-VI dataset). }\end{array}$ \\
\hline Intemational & $\begin{array}{l}\text { Dichotomous variable that accounts for the international activity of the firms ["0": Active } \\
\text { only nationally, "l": Active nationally and internationally] (source: CIS-VI dataset). }\end{array}$ \\
\hline Group & $\begin{array}{l}\text { Dichotomous variable that accounts for the firm's participation in a business group ["0": Not } \\
\text { part of a group, "l": Part of a group] (source: CIS-VI dataset). }\end{array}$ \\
\hline$E \boldsymbol{P}$ & $\begin{array}{l}\text { Electricity prices per consumption group in a country averaged over the } 2003-2005 \text { period } \\
\text { [Euro/kWh] (source: UK's Department for Business, Energy and Industrial Strategy dataset } \\
\text { on international industrial energy prices). }\end{array}$ \\
\hline R\&D & $\begin{array}{l}\text { Percentage of Research \& Development (R\&D) expenditures out of the total turnover of the } \\
\text { firm in } 2008 \text { (source: CIS-VI dataset). }\end{array}$ \\
\hline DSectors & $\begin{array}{l}\text { A vector of dichotomous variables that accounts for the type of sector the firm is active in, } \\
\text { according to the NACE Rev. } 2 \text { typology (source: CIS-VI dataset). }\end{array}$ \\
\hline
\end{tabular}

Table 4. Correlation matrix of the variables used in the econometric analysis.

\begin{tabular}{|c|c|c|c|c|c|c|c|c|c|c|c|c|}
\hline Variable & Mean & St Dev. & (1) & (2) & (3) & (4) & (5) & (6) & (7) & (8) & (9) & (10) \\
\hline (1) $E E I$ & 0.332 & 0.471 & 1 & & & & & & & & & \\
\hline (2) EEIprod & 0.247 & 0.431 & 0.747 & 1 & & & & & & & & \\
\hline (3) EEIproc & 0.256 & 0.437 & 0.881 & 0.563 & 1 & & & & & & & \\
\hline (4) iReg & 0.000 & 1.000 & 0.189 & 0.166 & 0.167 & 1 & & & & & & \\
\hline (5) isoc & 0.000 & 1.000 & 0.054 & 0.097 & 0.035 & 0.018 & 1 & & & & & \\
\hline (6) $L E$ & 0.130 & 0.336 & 0.158 & 0.101 & 0.168 & 0.055 & -0.025 & 1 & & & & \\
\hline (7) International & 0.479 & 0.500 & 0.136 & 0.081 & 0.139 & 0.091 & 0.044 & 0.134 & 1 & & & \\
\hline (8) Group & 0.324 & 0.468 & 0.118 & 0.076 & 0.122 & 0.110 & 0.023 & 0.310 & 0.199 & 1 & & \\
\hline (9) $E P$ & 0.000 & 1.000 & -0.081 & -0.031 & -0.095 & -0.057 & -0.124 & -0.208 & -0.268 & -0.253 & 1 & \\
\hline (10) $R \& D$ & 0.029 & 0.086 & 0.066 & 0.037 & 0.065 & -0.036 & -0.014 & -0.047 & 0.036 & -0.015 & 0.031 & 1 \\
\hline
\end{tabular}

Notes For sample stratification see Eurostat (2008, Table 2). 
Table 5. Percentages of firms that introduced (product, process of one of the two) EEIs in each country, broken down into two firm size classes (SMEs and LEs).

\begin{tabular}{|c|c|c|c|c|c|c|}
\hline \multirow{2}{*}{$\begin{array}{l}\text { Type of EEI } \\
\text { Firms size class }\end{array}$} & \multicolumn{2}{|c|}{$\begin{array}{l}\text { Percentage of firms that } \\
\text { introduced } E E I s\end{array}$} & \multicolumn{2}{|c|}{$\begin{array}{l}\text { Percentage of firms that } \\
\text { introduced product EEIs }\end{array}$} & \multicolumn{2}{|c|}{$\begin{array}{l}\text { Percentage of firms that } \\
\text { introduced process EEIs }\end{array}$} \\
\hline & SMES & LEs & SMES & LEs & SMES & LES \\
\hline Bulgaria & $17.99 \%$ & $29.00 \%$ & $10.11 \%$ & $17.22 \%$ & $14.99 \%$ & $26.58 \%$ \\
\hline The Czech Rep & $44.04 \%$ & $61.94 \%$ & $32.18 \%$ & $39.24 \%$ & $35.99 \%$ & $55.08 \%$ \\
\hline Germany & $44.84 \%$ & $66.02 \%$ & $30.56 \%$ & $48.13 \%$ & $37.05 \%$ & $59.21 \%$ \\
\hline Hungary & $47.69 \%$ & $65.19 \%$ & $21.84 \%$ & $25.13 \%$ & $42.05 \%$ & $61.05 \%$ \\
\hline Italy & $22.36 \%$ & $48.11 \%$ & $20.75 \%$ & $44.13 \%$ & $12.44 \%$ & $34.36 \%$ \\
\hline Lithuania & $14.70 \%$ & $32.37 \%$ & $9.09 \%$ & $17.26 \%$ & $13.01 \%$ & $30.21 \%$ \\
\hline Portugal & $34.66 \%$ & $58.55 \%$ & $26.99 \%$ & $40.04 \%$ & $28.13 \%$ & $51.51 \%$ \\
\hline Romania & $44.37 \%$ & $58.23 \%$ & $32.95 \%$ & $38.87 \%$ & $36.76 \%$ & $55.15 \%$ \\
\hline Slovakia & $39.31 \%$ & $48.92 \%$ & $27.27 \%$ & $34.76 \%$ & $29.97 \%$ & $45.06 \%$ \\
\hline Total & $30.07 \%$ & $54.12 \%$ & $22.70 \%$ & $38.24 \%$ & $22.49 \%$ & $46.57 \%$ \\
\hline
\end{tabular}

Notes For sample stratification see Eurostat (2008, Table 2). 
Table 6. Results of the bivariate and univariate probit models (1-3).

est. 
Table 7. Results of the bivariate probit model with a refined measure of firm size.

models $(R h o)$ from zero is tested with a Wald test.

hmark; The difference in correlation between the two 


\section{FIGURES}

Figure 1. Marginal effects of regulatory (iReg) and social (iSoc) institutional pressures on the probability of energyefficiency innovation (EEI) in SMEs and LEs.

Notes: All other variables are kept at their mean value; 90\% Pointwise Confidence Intervals (CIs) are presented; Weak refers to the minimum value, while Strong refers to the maximum value of the variable.
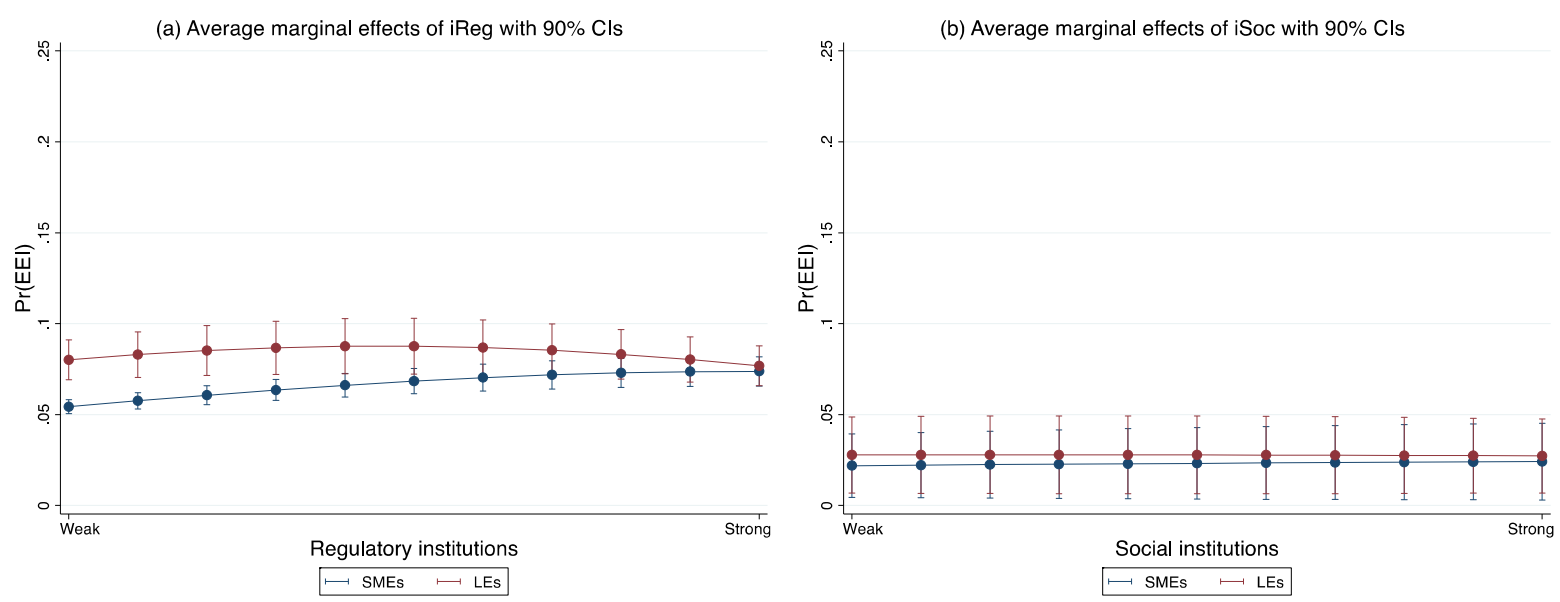

Figure 2. Marginal effects of regulatory (iReg) and social (iSoc) institutional pressures on the probability of product (EEIprod) and process (EEIproc) energy-efficiency innovation in SMEs and LEs.

Notes: All other variables are kept at their mean value; 90\% Pointwise Confidence Intervals (CIs) are presented; Weak refers to the minimum value, while Strong refers to the maximum value of the variable.
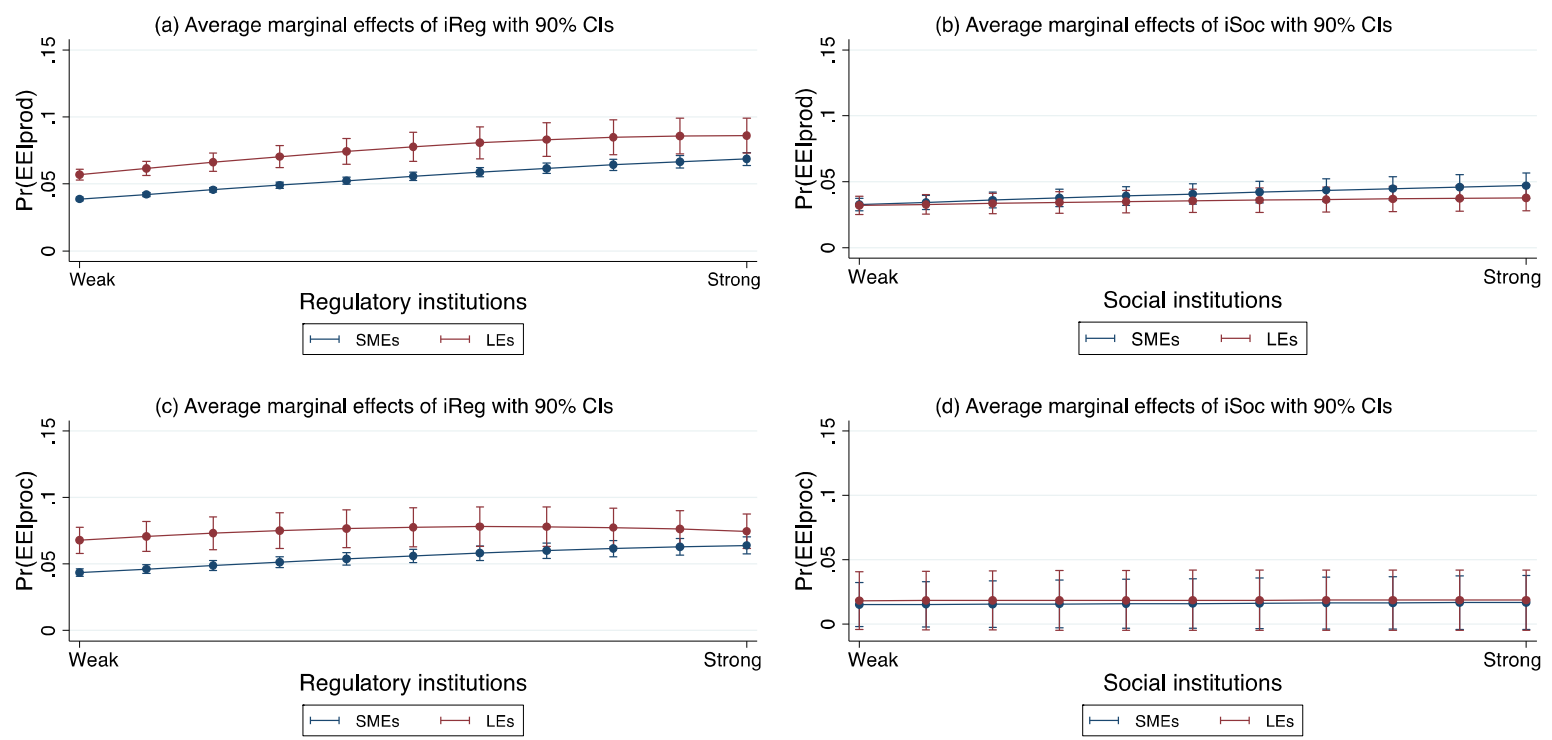